\title{
COMPARATIVE ANALYSIS OF FARMING VARIETY OF PEANUT NOLION 1 AND NOLION 2 IN THE DISTRICT OF SOUTH TOTIKUM BANGGAI KEPULAUAN
}

\author{
Radia N. Bonenehu ${ }^{1)}$, Made Antara ${ }^{2)}$, Rustam Abd Rauf ${ }^{2)}$ \\ ${ }^{1)}$ Departement of Agriculture and Horticulture Banggai Islands District Central Sulawesi Province, \\ e-mail : radiabonenehu@gmail.com \\ ${ }^{2)}$ Lecturer and Researcher at Department of Agribusiness Faculty of Agriculture.University of Tadulako, Palu.
}

\begin{abstract}
This study aims to: (1) Knowing large farm income peanut varieties Nolion 1 and Nolion 2 in District Totikum South Banggai Islands, and (2) Determine the ratio of production and farm income peanut varieties Nolion 1 and Nolion 2 in District Totikum South Banggai Islands, research type used in this research is descriptive analysis with comparative research method is ex post facto. Sampling is done by simple random sampling method (simple random sampling) take $15 \%$ of the population with sampling technique Proportional Stratified Random Sampling. Analysis of data using revenue analysis and comparative analysis / comparison of the average production and average farm income of farmers responder peanut varieties Nolion Nolion 1 and 2 . The results show the average farmer's income respondents peanut farmers varieties Nolion 1 in one process location

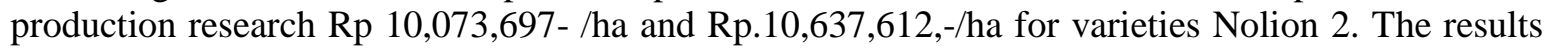
of comparative analysis (Compare Independent samplest-test) is obtained, there are differences in average production and income of farmers varieties with varieties Nolion 1 and Nolion 2, on the level of $\alpha 5 \%$. Conclusion of the study that there is a difference in the average production and average farm income farm Nolion 1 peanut varieties and varieties of peanut farming Nolion 2.
\end{abstract}

Key Words : Income, nolion variety 1 and nolion variety 2, production.

\section{INTRODUCTION}

Development of the agricultural sector very important in the national food sufficiency. The success of the development of this sector, especially food crops is expected to ensure food security rooted in the diversity of food resources, institutional, and local culture. According Adiratma (2004), the agricultural sector plays a very important in the economy of Indonesia. One of the agricultural commodities that can help increase the income and welfare of farmers is peanuts (Arachis hypogaea, L). Peanut is a commodity beans are grown in Indonesia.

The need and demand for peanuts from the processed food industry sector spur increased the income of farmers in different regions. Processed foods with raw materials peanut experiencing increasing demand. Peanut production in the country over the last three decades showed positive growth. However, the production can not meet the demand increases, so the amount of imports also rose sharply peanuts. Demand for processed peanuts remain high every year (SitiNurShaliha, 2015).

Banggai Islands is one of the peanut production areas in Central Sulawesi province ranks first, which in 2015 recorded peanut production 1177.23 tons of harvested area of 776 ha is still far from production peanut provincial level reached 4942.76 tons 2,928 ha of harvested area, with the achievements of the productivity of 1,517 tons / ha lower than the productivity of peanut provincial level amounted to 1.688 ton/ha.

Banggai Kepulauan Regency has two local seed varieties that have been 
released varieties are varieties Nolion 1 by the Minister of Agriculture of the Republic of Indonesia Number: 1178 / kpts / SR.12 / 11/2014 and Varieties Nolion 2 Decree of the Minister of Agriculture of the Republic of Indonesia Number: 1177 / kpts / SR.12 / $11 / 2014$. Increased productivity of groundnut needs to be done in line with the increase demand for peanuts.

\section{RESEARCH METHODS}

This study was conducted in the District of South Totikum Banggai Islands. Location District of South Totikum determined intentionally (purposive), with the consideration that this district is peanut production areas in the Banggai Islands. The research was conducted on the Moon from September to October 2016.

Determination of the number of samples based approach to the number of farmers planting peanut varieties Nolion1 and varieties Nolion 2.

Results of preliminary observations at the study site obtained the total population peanut farmers varieties Nolion 1 and varieties Nolion 2 are located in District South Totikum sample of three villages, namely the village of 199 households Nulion, Tobungku village of 147 households, the village of 152 households Peley. The total population of 498 people. The state of relatively homogeneous population based on the vast land.

Sampling method was randomly simple (Simple Random Sampling) with sampling technique Proportional Stratified Random Sampling (Sugiyono, 2007).

Each unit or units of the other unit has an equal chance to be selected. Determination of the amount of sample using methods Slovin, because of the number of known populations.

$$
\mathrm{n}=\frac{\mathrm{N}}{1+\mathrm{Ne}^{2}}
$$

Description:

$\mathrm{n}=$ number of samples (respondents)

$\mathrm{N}$ = number of population

$\mathrm{e}=$ error rate $(15 \%)$
Table 1. Total population and sample in the District of South Totikum, 2016

\begin{tabular}{llcccc}
\hline \multirow{2}{*}{ No. Rural } & \multicolumn{2}{c}{ Population } & \multicolumn{2}{c}{ Sample } \\
& & Nolion 1 & Nolion 2 & Nolion 1 & Nolion 2 \\
\hline 1 & Nulion & 76 & 123 & 8 & 13 \\
2 & Tobungku & 46 & 101 & 5 & 11 \\
3 & Peley & 34 & 118 & 4 & 12 \\
\hline \multicolumn{1}{l}{ Total } & 156 & 342 & 17 & 36 \\
\hline
\end{tabular}

Source: Primary Data 2016.

By using this equation, where $\mathrm{N}=$ 498 and $n=25$. So the magnitude of the samples obtained are as follows :

1. Number of respondents farmer farming peanut varieties Nolion 1 in the District I South Totikum $=\frac{156}{498} \times 53=16.60$, rounded up to 17 people.

2. Number of farmers farming respondents peanut varieties Nolion 2 in the District of South Totikum $=\frac{342}{498} \times 53=36.40$, rounded up to 36 people.

Population and sample per village as much as 3 more villages are listed in Table 1.

This study uses primary data and secondary data. Primary data were collected through direct observation and interviews with respondents who assisted farmers by using a list of questions (questionnaire), while the secondary data obtained from the Office/agencies have particular relevance to the objectives of this research.

Analysis of the data used in this study is a qualitative and quantitative analysis. Qualitative analysis is used to determine a general overview and explain the costs and revenues peanut farmers in the location of the decomposed descriptive study. The quantitative analysis used is the analysis of costs and farm income, comparative analysis.

Farming Revenue Analysis. Model analysis used to determine the peanut farm income using Variety Nolion 1 and Variety Nolion 2 (Soekartawi, 2002) is:

$$
\begin{aligned}
& \Pi=\mathrm{TR}-\mathrm{TC} \\
& \mathrm{TR}=\mathrm{Y} \cdot \mathrm{Py} \\
& \mathrm{TC}=\mathrm{FC}+\mathrm{VC}
\end{aligned}
$$


Description:

$\Pi$ : Farming Net

TR : Total Revenue

TC : Total Cost (Total Cost)

Y : Production obtained

Py : Price of production

FC : Fixed Costs

VC : Variable Cost

Comparative Analysis. hypothesis testing is done by using t-test two independent samples Separated variance (variance separated) (Sugiyono, 2007) defined as follows:

$\mathrm{t}(\mathrm{t}$-test $)=\frac{\mu 1-\mu 2}{s^{2} g a b \sqrt{\frac{1}{n 1}}+\frac{1}{n 2}}$

where: $S^{2} G a b=\frac{(n 1-1) S 1^{2}+(\mathrm{n} 2-1) S 2^{2}}{n 1+n 2-2}$

degrees free $(\mathrm{db})=\mathrm{n}_{1}+\mathrm{n}_{2}-2$ at the level of $0.05 \tilde{\alpha}$

Where: $\mathrm{t}=$ the critical region.

Description:

$\mu_{1}=$ Average production and farm income peanut varieties Nolion 1

$\mu_{2}=$ Average production and farm income peanut varieties Nolion 2

$S_{g a b}=$ Standard deviation of the sample combined

$n_{1}=$ Number of samples VareitasNolion 1

$n_{2}=$ Number of samples VareitasNolion 2

$S_{1}=$ Standard deviation of Respondents Variety Nolion 1

$S_{2}=$ Standard deviation of Respondents Variety Nolion 2

$\mathrm{Db}=$ Degrees free

Shape statistical hypothesis:

Ho: $\mu_{1}=\mu_{2:}$ means there is no difference in production and incomes among farming peanut varieties Nolion 1 and Nolion 2

$\mathrm{H}_{1:} \mu_{1} \neq \mu_{2}$ : means that there are differences in production and farm income peanut varieties Nolion 1 of Nolion 2

Testing the hypothesis by using criteria as follows:
- If $\mathrm{t}$ arithmetic $\leq \mathrm{t}$ table, $\mathrm{H}_{\mathrm{o}}$ accepted it means that there is no difference between the production and income of farmers peanut varieties Nolion 1 with Nolion 2 at $95 \%$ confidence level

- If $\mathrm{t}$ arithmetic $>\mathrm{t}$-table, $\mathrm{H}_{1}$ accepted it means that there are differences in the production and income of farmers peanut varieties Nolion1 and varietiesNolion 2 at the $95 \%$ confidence level.

\section{RESULTS AND DISCUSSION}

Revenue Analysis Farming. Analysis of income in this study to determine the amount of profit or net income of farmers responder farming peanuts using varieties Nolion 1 or varieties Nolion 2 Village Nulion, Tobungku and Peley during one growing season by calculating the difference between total revenue (Total Revenue (TR)) and total production cost (Total Cost (TC)) which are issued.

The results obtained by analysis of the average number of net income (profit) received by farmers from farming peanuts respondents, more seen in Table 2.

Table 2 shows the average amount of revenue obtained by farmers respondents peanut varieties Nolion 1 with the calculation of production multiplied prevailing product prices as much as $\mathrm{Rp} 14,483,193$ / ha. Average production of peanuts, amounting to $1,609 \mathrm{~kg} / \mathrm{ha}$ with a selling price of peas

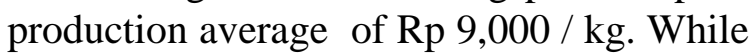
the average amount of revenue that the respondent peanut farmer varieties Nolion 2 amounted to Rp 17,097,887 / ha. Average production of peanuts, amounting to 1,900 $\mathrm{kg} / \mathrm{ha}$ with an average selling price of Rp 9,000/kg.

Average profit (net income) farmers using varieties Nolion 1 Village Nulion, Tobungku and Peley District of South Totikum during one growing season as much as Rp 10,073,697/ha,-Average income (net income) farmers using varieties Nolion 2 Village Nulion, Tobungku and Peley during one growing season as much as Rp 10,637,612/ha,- 
Table 2. Average Revenue, Costs, Production, Revenue and RC ratio Farmers Respondents Varieties Nolion 1 and varieties Nolion 2 Village Nulion, Tobungku and Peley per hectare, 2016

\begin{tabular}{lrr}
\hline \multicolumn{1}{c}{ Description } & \multicolumn{2}{c}{ Value (US \$ / ha) } \\
& Var. Nolion 1 & \multicolumn{1}{c}{ Var. Nolion 2 } \\
\hline A. Reception & & \\
1. Production (kg / ha) & 1,609 & 1,900 \\
2. Selling Price (USD / kg) & $14,483,193$ & 9,000 \\
\hline Number of A = (Prod x HRG Sell) & & $17,097,887$ \\
\hline B. Cost of Production & & \\
a. Fixed cost & 31.028 & 29.930 \\
1. The land tax (USD) & 49.606 & 68.496 \\
2. Depreciation Equipment & - & - \\
3. Land Lease (USD) & 80.633 & 98.425 \\
\hline Total A & & $1,474,961$ \\
\hline b. variable costs & $1,441,500$ & 173.709 \\
1. Seed (USD / kg) & 80.155 & 70.520 \\
2. Fertilizers (USD / kg) & 71.267 & $2,735,941$ \\
3. Pesticides (USD / Ltr / kg) & $4,642,660$ & $6,361,851$ \\
\hline 4. Labor Wages & $4,328,862$ & $6,460,276$ \\
\hline Total (b) & $4,409,496$ & $10,637,612$ \\
\hline C. Total cost ( A + B) (USD) & $10,073,697$ & \\
\hline D. Revenue (USD) & & \\
\hline
\end{tabular}

Source: Primary Data After Being Processed, 2016.

Analysis of Differences in Average Production Peanut. $T$ test results are known differences in farm production Peanut Variety Nulion1 and Variety Nulion 2 , homogeneity of variance test results $\mathrm{p}$ value $=0,000$ (sig. 0.000$)$ is less than 0.05 , indicating reject $\mathrm{Ho}$ at level $\alpha 5 \%$ 2-way test, means that there are differences in production between Nolion 1 and Nolion2 in the village Nolion, Tobungku and Piley District of South Totikum, where the average production of respondents varieties Nolion 2 higher than the varieties Nolion 1. The value of t-test is obtained by - 1,749 smaller than t-table $(0.05 ; 51)=2.007$.

The difference between the average production of varieties of peanut farming varieties Nolion 1 with peanut varieties Nolion 2, amounting to $291 \mathrm{~kg}$ of dry pods / ha, this happens because influenced by the factors of production (input). Technically peanut production rate is determined by the ability to manage through the four components of farming technology is the use of seeds, fertilizers, pesticides and labor, on the other hand, the production of which was obtained largely determine the amount of income, while income levels are influenced by the cost of production and selling price.

Comparisons are most evident in variable costs respondents where varieties Nolion 2 pretty much cost is Rp. 6,361,851/ha and the respondent varieties Nolion 1 only cost Rp.4,328,862,-/ha. The average use of fertilizer on the variety Nolion PPC 2 is 3.64 liters/ha, while the varieties Nolion 1 was 1.75 liters/ha, shows a higher use of fertilizers on the variety Nolion 2 encourage increased production per hectare. Similarly, for the labor of respondents varieties Nolion 2 more use of the labor force of 59 persondays/ha, while varieties Nolion 1 using a workforce of 49 person-days/ha. Labor is the most important factor in the production process is not only seen on the availability of labor but also the quality and kinds of labor need to be considered. 
According Saptana et al., (2010) states that the use of labor intensive also related to the effort to address the risks interactively manage the farming seriously. This means that the addition of the use of labor will be to mitigate the risks of farming.

\footnotetext{
Analysis of Differences in Average Income. $t$ test result differences in production and income in Table 2 can be known differences Peanut farm production Variety Nulion 1 and Variety Nulion 2, homogeneity of variance test results $\mathrm{p}$ value $=0,017$ (sig.0.017) is less than 0.05, indicating reject $\mathrm{Ho}$ at level $\alpha$ of 5\% 2-way test, it means that there is a difference in income between Nolion 1 and Nulion 2 in the village Nolion, Tobungku and the District Piley South Totikum, where the average income of respondents varieties Nolion 2 higher than the NulionNolion 1 . The value of t-test is obtained by -6.481 smaller than t-table $(0.05 ; 51)=2.007$.

The difference between the average production of varieties of peanut farming Nulion Nolion 1 with peanut varieties Nolion 2, amount Rp. 563.915,-/ha.
}

\section{CONCLUSIONS}

\section{Conclusion}

Based on the results, it can be concluded that:

1. The average production of farm peanut varieties Nolion 1 amounted to $1,609 \mathrm{~kg}$ of dry pods/ha and an average production of farm peanut varieties Nolion 2 amounted to $1,900 \mathrm{~kg}$ of dry beans pods/ha Village Nulion, Tobungku and Peley District of South Totikum Banggai Islands.

2. The average income of farmers varieties of peanut farming varieties Nolion 1 Rp.10,073,697,-/ha, and the average income of farmers farming peanut varieties Nolion 2 Rp.10.637.612,-/ha in the village Nulion, Tobungku and Peley South Totikum Subdistrict, Banggai Islands.

3. There is a marked difference between the average production and the average income of peanut farming varieties Nolion 1 with the average production of peanuts in varieties Nolion 2 in village Nolion, Tobungku and Peley sub districts of Totikum Selatan.

\section{REFERENCES}

Adiratma ER, 2004. Stop Planting Rice: Rice Farmers' Thinking Condition Indonesia and Efforts to Improve Welfare of Farmers. Sower Swadaya, Jakarta.

Siti Nur Shaliha, 2015. Outlook Food Peanut. In Leli Nuryati, Budi Waryanti, Noviati and Roch Widaningsih. J. ISSN-1907-1507. Data Center and Information Systems Agriculture. Ministry of Agriculture, Jakarta

Decree of the Minister of Agriculture, 2014. The Agriculture Decree No.1177 / kpts / SR.12 / 11/2014. Jakarta.

Sugiyono, 2007. Qualitative and Quantitative Research Methods R\&D. Molds 19th. CV Alfabeta, Bandung

Soekartawi, 2002. Farming Systems Analysis. UI Press. Jakarta

Saptana, A. Daryanto., HK Daryanto and Kuntjoro. 2010. Risk Management Strategy Peasant Red Chili On Lowland Rice Field in Central Java. J. of Management and Agribusiness 7 (2): 115-131. 